\title{
Microstructure and Creep Rupture Properties of a Low Si-12Cr-Mo-V-Nb Steel*
}

\section{By Ik-Min PARK,** Toshio FUJITA ${ }^{* * *}$ and Kentaro ASAKURA***}

\section{Synopsis}

The beneficial characteristic of low-Si steels, little segregation and homogeneous mechanical properties in large ingots, was applied to a $12 \mathrm{Cr}$ steel. The studies of the microstructures and creep rupture properties for a low $\mathrm{Si}-12 \mathrm{Cr}-1.5 \mathrm{Mo}-0.2 \mathrm{~V}-0.05 \mathrm{Nb}$ steel after various heat treatments were carried out. The creep recovery mechanism, the precipitation characteristics of $\mathrm{M}_{23} \mathrm{C}_{6}$ and the dissolution and coagulation of the fine precipitates were investigated by the aid of transmission electron microscope. Furthermore, the effects of prior tempering temperature and creep stress on the microstructures and mechanical properties were also investigated.

This steel exhibits a superior creep rupture strength, 1.4 times that of the conventional super $12 \mathrm{Cr}$ rotors. The austenitizing temperature effective for the long term creep strength was found to be in the range of $1050^{\circ}$ to $1100^{\circ} \mathrm{C}$ and optimum prior tempering temperature was about $700^{\circ} \mathrm{C}$.

\section{Introduction}

In order to improve the thermal efficiency of a steam turbine in the power plant, there is a trend towards increasing the unit size and operating temperature of the steam turbine. ${ }^{1,2)}$ As turbine rotors becoming large in size and increasing in the operating temperature and pressure, materials with high creep rupture strength and good toughness have been strongly required. To give good strength and toughness, $1 \% \mathrm{Cr}-\mathrm{Mo}-\mathrm{V}$ steel for $\mathrm{HP}$ and $\mathrm{IP}$ rotors and $3 \frac{1}{2} \% \mathrm{Ni}-\mathrm{Cr}-\mathrm{Mo}-\mathrm{V}$ steel for $\mathrm{LP}$ rotors have been used. ${ }^{3)}$ Recently, to obtain high creep rupture strength, turbine rotors are made from super $12 \mathrm{Cr}$ steels. For example, there are $12 \mathrm{Cr}-\mathrm{Mo}-\mathrm{V}-\mathrm{Nb}-\mathrm{N}$ steel rotors ${ }^{4)}$ in U.S.A. and $12 \mathrm{Cr}-\mathrm{Mo}-\mathrm{V}-\mathrm{Ta}-\mathrm{N}$ steel rotors ${ }^{5)}$ in Japan.

The tempering resistance of $12 \mathrm{Cr}$ steels can be improved by increasing the secondary hardening; this is achieved either by increasing the coherent strains or increasing the volume fraction of precipitates. ${ }^{6)}$ It is possible to increase the coherent strains by increasing the lattice parameter of the $\mathrm{M}_{2} \mathrm{X}$ or $\mathrm{MX}$ precipitates within the martensite lath and decreasing the lattice parameter of the ferrite matrix. Silicon is one of the few elements which decrease the lattice parameter of the ferrite matrix, and imparts some resistance against the oxidation. ${ }^{7)}$ It is considered that increasing the silicon content is beneficial in the point of the oxidation-resistance and the secondary hard- ening. On the other hand, in recent researches, ${ }^{8)}$ it has been observed that large ingots of low-Si steels have little macro-segregation and homogeneous mechanical properties. The first object of this paper is the application of this last new beneficial characteristic to super $12 \mathrm{Cr}$ rotors.

The chemical composition of the steel studied in this work was modified from that of the TAF steel. ${ }^{9-11)}$ The Si content was decreased from $0.5 \%$ to $0.02 \%$ by VCD (Vacuum Carbon Deoxidation) process, while the $\mathrm{Nb}$ content was decreased from $0.2 \%$ to $0.05 \%$ in order to depress the effective solution treatment temperature, and boron was not added in order to improve the forgeability.

There were constant researches ${ }^{6,7,12-14)}$ for the microstructure and creep rupture properties of $12 \mathrm{Cr}$ steels, but they did not provide a full explanation of high temperature properties. The study by X-ray diffraction method of extracted carbides gives only a partial information of the change of carbides of reasonable size, and microstructure study by the extraction replicas do not give enough information of the recovery of the matrix. A microstructure study of unstressed specimens tempered for short time at various temperatures is inadequate to explain the long term creep rupture properties. To give more explanation of the long term creep rupture properties, we investigated the microstructures of crept specimens up to $9000 \mathrm{~h}$ by thin foils. According to this research, the model of the creep recovery mechanism for $12 \mathrm{Cr}$ steels is established. The effect of austenitizing temperature, prior tempering temperature, and creep stress on the microstructures and mechanical properties, and the precipitation characteristics of $\mathrm{M}_{23} \mathrm{C}_{6}$ are also investigated.

\section{Experimental Procedure}

The chemical composition of the steel studied in this work is given in Table 1 . The alloys were cast into $30 \mathrm{~kg}$ ingots by vacuum induction melting and then forged at about $950^{\circ}$ to $1100^{\circ} \mathrm{C}$ to bars of $20 \mathrm{~mm}$ or $10 \mathrm{~mm}$ square. The specimens for creep rupture tests were solution treated at $1050^{\circ}$ to $1150^{\circ} \mathrm{C}$ for

Table 1. Chemical composition of the specimen (wt\%).

\begin{tabular}{cccccccccccccc}
\hline $\mathrm{C}$ & $\mathrm{Si}$ & $\mathrm{Mn}$ & $\mathrm{P}$ & $\mathrm{S}$ & $\mathrm{Ni}$ & $\mathrm{Cr}$ & $\mathrm{Cu}$ & $\mathrm{Mo}$ & $\mathrm{V}$ & $\mathrm{Nb}$ & $\mathrm{N}$ & $\mathrm{Al}$ \\
\hline 0.19 & 0.02 & 0.33 & 0.003 & 0.009 & 0.02 & 11.07 & 0.01 & 1.48 & 0.21 & 0.043 & 0.021 & 0.005 \\
\hline
\end{tabular}

* Originally published in Tetsu-to-Hagané, 66 (1980), 82, in Japanese. English version received May 28, 1979.

** Graduate School, The University Tokyo, Hongo, Bunkyo-ku, Tokyo 113.

*** Department of Materials Science, Faculty of Engineering, The University of Tokyo, Hongo, Bunkyo-ku, Tokyo 113. 
$30 \mathrm{~min}$ and oil quenched (or air cooled), and then tempered at $700^{\circ} \mathrm{C}$ for $1 \mathrm{~h}$ (or $570^{\circ} \mathrm{C}+620^{\circ} \mathrm{C}$ for $1 \mathrm{~h})$.

Creep specimens with a parallel gauge length of $30 \mathrm{~mm}$ were tested by conventional single specimen machines or multi specimen machines. Testing temperature was in the range $550^{\circ}$ to $700^{\circ} \mathrm{C}$ and the loads were chosen to give rupture times from a few hours to $100000 \mathrm{~h}$. Determinations of Vickers hardness were made at room temperature using a $20 \mathrm{~kg}$ load.

The carbides were extracted in a $5 \% \mathrm{HCl}+95 \%$ ethanol solution at a current density of 0.02 to $0.03 \mathrm{~A} /$ $\mathrm{cm}^{2}$. X-ray diffraction studies of extracted residues were made mainly using $\mathrm{Mo}-\mathrm{K}_{\alpha}$ and $\mathrm{Cr}-\mathrm{K}_{\alpha}$ radiations. Si powder was used as a internal standard for the lattice parameter measurements. Carbon extraction replicas were prepared by etching initially in Villela's reagent and stripped in a $25 \% \mathrm{HCl}+25 \% \mathrm{HNO}_{3}+$ $50 \%$ ethylene-glycol solution. Thin foils were prepared from the gauge length of crept specimens, and ground mechanically to $0.1 \mathrm{~mm}$; subsequent electrolytic polishing was performed in an $80 \% \mathrm{H}_{3} \mathrm{PO}_{4}+$ $20 \% \mathrm{CrO}_{3}$ solution, and for the final stages in a $135 \mathrm{gCH}_{3} \mathrm{COOH}+25 \mathrm{gCrO}_{3}+7 \mathrm{gH}_{2} \mathrm{O}$ solution. Thin foils were examined in a $150 \mathrm{kV}$-electron microscope. The dislocation density was measured according to the method of $\mathrm{Ham} ;^{15}$ the thin foils thickness had been assumed to be $2500 \AA$.

\section{Experimental Results and Discussion}

\section{Creep Rupture Strength}

The results of the creep rupture tests are shown in

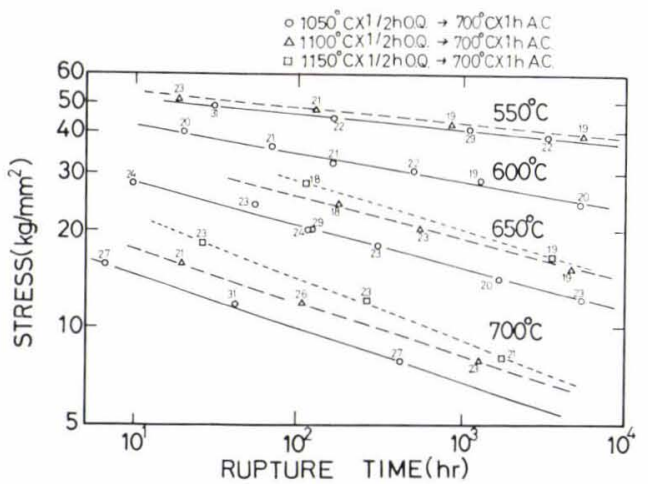

Fig. 1. Creep rupture properties of the oil-quenched specimen.

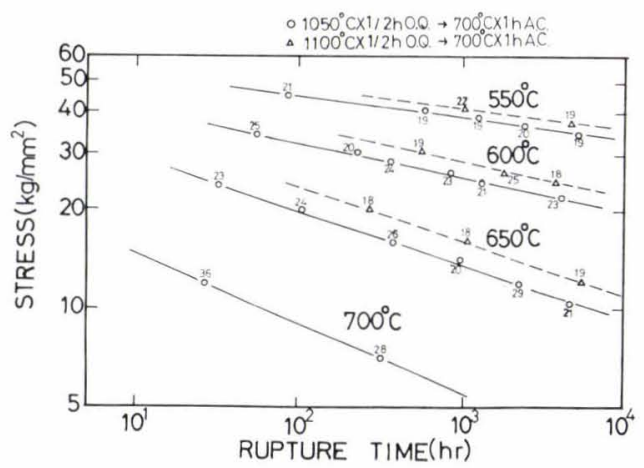

Fig. 2. Creep rupture properties of the air-cooled specimen.
Figs. 1 to 3 . The $1000 \mathrm{~h}$ rupture strength of this steel is about $39 \sim 41 \mathrm{~kg} / \mathrm{mm}^{2}$ at $550^{\circ} \mathrm{C}$ and $25 \sim$ $28 \mathrm{~kg} / \mathrm{mm}^{2}$ at $600^{\circ} \mathrm{C}$. The creep rupture elongation is about $20 \%$ in the temperature range of $550^{\circ}$ to $650^{\circ} \mathrm{C}$.

Comparison of this rupture strength with that of various rotor steels as expressed in the Larson-Miller parameters (Fig. 4) shows that this low $\mathrm{Si}-12 \mathrm{Cr}-\mathrm{Mo}-$ $\mathrm{V}-\mathrm{Nb}$ steel has a superior creep rupture strength 1.4 times that of the conventional super $12 \mathrm{Cr}$ rotor steels. ${ }^{16)}$ The $100000 \mathrm{~h}$ rupture strength (at $550^{\circ} \mathrm{C}$ ) of conventional super $12 \mathrm{Cr}$ rotors is about $22 \mathrm{~kg} / \mathrm{mm}^{2}$, whereas that of this steel is about $30 \mathrm{~kg} / \mathrm{mm}^{2}$. It is considered that this superior creep rupture strength is attributed to the high secondary hardening, achieved by the optimum additioning of alloying elements, especially of $\mathrm{Mo}, \mathrm{V}$ and $\mathrm{Nb}$. It will be noted that the composition of this steel differs from that of conventional super $12 \mathrm{Cr}$ rotors, mainly in $\mathrm{Mo}$ and $\mathrm{N}$ contents. ${ }^{4,16)}$ Superior creep rupture strength of this steel implies that increasing the contents of Mo, which gives rise to the solid solution hardening as well as precipitation hardening, is very effective on the long term creep rupture strength at $550^{\circ}$ to $600^{\circ} \mathrm{C}$. The optimum additioning amounts of nitrogen is considered about $0.02 \%$ in case of the $0.2 \%$ carbon base steels. Additioning of nitrogen above $0.05 \%$ gave low creep rupture strength in long term test in the temperature range of $550^{\circ}$ to $600^{\circ} \mathrm{C}$ in our previous work. ${ }^{17)}$

\section{Effect of Austenitizing Temperature}

As austenitizing temperature increases from $1050^{\circ}$ to $1100^{\circ} \mathrm{C}$, the $1000 \mathrm{~h}$ rupture strength increases about $2 \sim 3.5 \mathrm{~kg} / \mathrm{mm}^{2}$, whereas creep rupture elongation de-

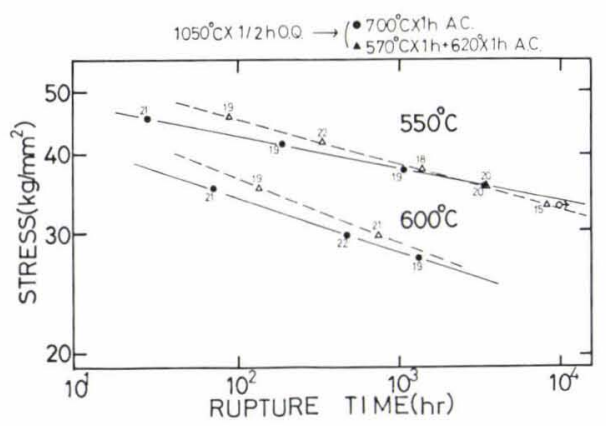

Fig. 3. Effect of prior tempering temperature on creep rupture properties.

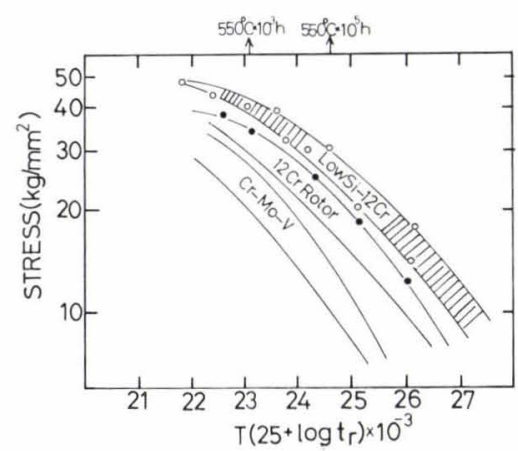

Fig. 4. Creep rupture strength of various rotors. 
creases about $3 \sim 5 \%$ in the temperature range of $550^{\circ}$ to $700^{\circ} \mathrm{C}$. However, the $1150^{\circ} \mathrm{C}$ solution treated steels exhibit almost the same creep rupture strength in long term tests as that of the $1100^{\circ} \mathrm{C}$ solution treated steels.

The effect of austenitizing temperature on prior austenite grain size and on hardness are shown in Fig. 5. The rapid change of the prior austenite grain size was observed in the temperature range of $1050^{\circ}$ to $1150^{\circ} \mathrm{C}$. This rapid change may be attributed to the solubility change of the undissolved carbides such as $\mathrm{NbC}, \mathrm{M}_{23} \mathrm{C}_{6}$, which have a grain-refining effect.

If the creep recovery mechanism of $12 \mathrm{Cr}$ steels is mainly controlled by the dislocation climb which can be resisted by the dislocation pinning action of fine precipitates, the amounts of precipitates, precipita-

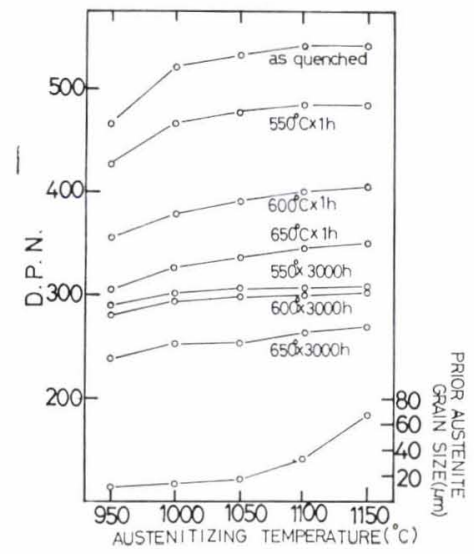

Fig. 5. Effect of austenitizing temperature on prior austenite grain size and hardness.

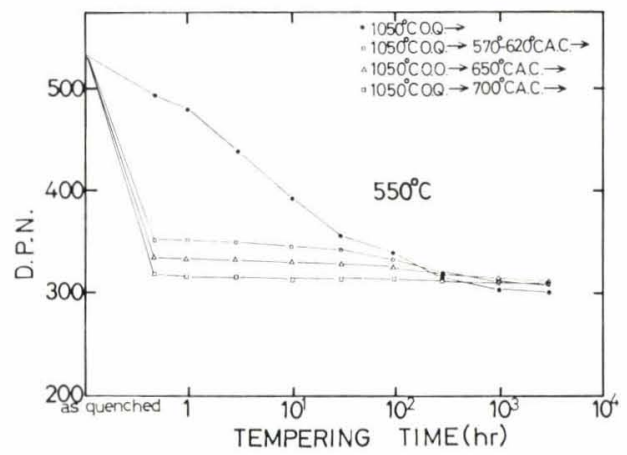

Fig. 6. Effect of prior tempering temperature on hardness. tion rate and the degree of the agglomeration of $\mathrm{M}_{23} \mathrm{C}_{6}$ are important factors of the creep resistance. The solubility change by the different solution treatment temperature makes differences in the above factors. In the $1100^{\circ} \mathrm{C}$ and $1150^{\circ} \mathrm{C}$ solution-treated steels, however, it is considered that these differences become small in the long term test. Though it is generally expected that the specimen with large grain size exhibits higher creep resistance than that of small grain size, this expectation was deviated in case of the $1150^{\circ} \mathrm{C}$ solution treated steels. This fact implies that prior austenite grain size is not an important factor when grain size is above $40 \mu \mathrm{m}$ in diameter. Rather than prior austenite grain size, the solubility, and the morphology of the martensite lath are considered more important factors. Unfortunately, the study of the morphology of the martensite lath was outside the scope of this investigation.

\section{Effect of Prior Tempering Temperature}

In order to investigate the effect of prior tempering temperature on the creep rupture properties, two kinds of specimens were prepared. One was tempered at $700^{\circ} \mathrm{C}$, that is $150^{\circ} \mathrm{C}$ above the creep rupture testing temperature, and the other was two-step tempered at $570^{\circ} \mathrm{C}$ and $620^{\circ} \mathrm{C}$, this is the tempering treatment for conventional super $12 \mathrm{Cr}$ rotor steels. In short term test, the two-step tempered steels exhibit higher creep rupture strength than the $700^{\circ} \mathrm{C}$ tempered steels (Fig. 3). In long term test (about $3000 \mathrm{~h}$ ), however two kinds of specimens exhibit almost the same value of creep rupture strengths, and it is expected that the $700^{\circ} \mathrm{C}$ tempered steels exhibit higher creep rupture strengths in longer term test. The hardness change of the annealed steels shows the same tendency as the creep rupture properties (Fig. 6). This fact indicates that the $700^{\circ} \mathrm{C}$ tempered steel, which has a low strength in prior tempered condition but exhibits high softening resistance in long term test, is beneficial for long term creep rupture properties.

The electron micrograph (Photo. 1 (a)) of the tempered steel at $700^{\circ} \mathrm{C}$ for $1 \mathrm{~h}$ shows a typical lath martensite structure which contains $\mathrm{M}_{23} \mathrm{C}_{6}$ at the lath boundary and very fine precipitates $(\approx 100 \AA)$ within the lath. On the other hand, the electron micrograph (Photo. 1 (b)) of the two-step tempered steel shows a metastable structure which appears in

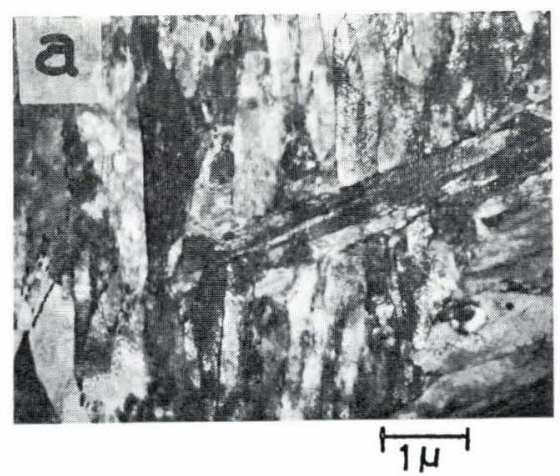

(a) $700^{\circ} \mathrm{C} \times 1 \mathrm{~h}$

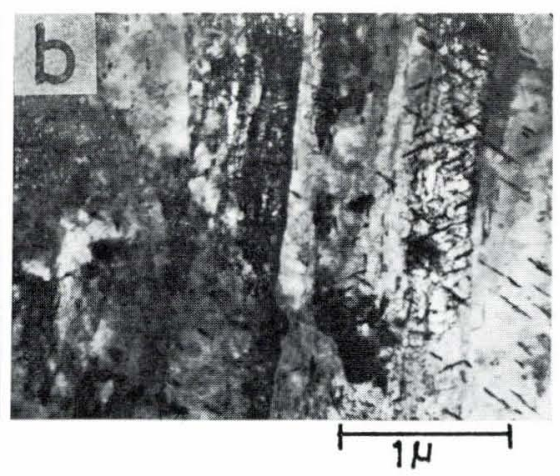

(b) $\left(570^{\circ} \mathrm{C}+620^{\circ} \mathrm{C}\right) \times 1 \mathrm{~h}$

Photo. 1. Transmission electron micrographs showing influence of prior tempering temperature. 
the stage of $\mathrm{M}_{3} \mathrm{C} \rightarrow \mathrm{M}_{7} \mathrm{C}_{3}$ transformation. The main difference in microstructural change between the $700^{\circ} \mathrm{C}$ tempered steels and the two-step tempered steels is considered to be the difference of the degree of $\mathrm{M}_{3} \mathrm{C} \rightarrow \mathrm{M}_{7} \mathrm{C}_{3}$ transformation. The two-step tempered steels has the higher transformation degree than the $700^{\circ} \mathrm{C}$ tempered steels. Inferior creep rupture strength of the two-step tempered steel is probably attributed to the higher transformation degree which gives rise to high dislocation mobilities associated with intense diffusion on the stage $\mathrm{M}_{3} \mathrm{C} \rightarrow \mathrm{M}_{7} \mathrm{C}_{3}$ reaction.

\section{Precipitates}

Precipitate identification was made by selectedarea diffraction on both replicas and thin foils and Xray diffraction on extracted residues. Identified precipitates in the unstressed specimens were $\mathrm{M}_{3} \mathrm{C}, \mathrm{M}_{7} \mathrm{C}_{3}$, $\mathrm{M}_{23} \mathrm{C}_{6}$ and $\mathrm{MX}$ (Table 2). A typical carbide transformation in $\mathrm{Cr}$ containing steels was observed. ${ }^{18)}$ The $\mathrm{M}_{7} \mathrm{C}_{3} \rightarrow \mathrm{M}_{23} \mathrm{C}_{6}$ transformation starts from $100 \mathrm{~h}$ at $550^{\circ} \mathrm{C}$, from $10 \mathrm{~h}$ at $600^{\circ} \mathrm{C}$, and from $1 \mathrm{~h}$ at $650^{\circ} \mathrm{C}$. Hardness change as a function of the tempering time in the annealed steels is shown in Fig. 7. This shows hardness decreases rapidly in the stage of the carbide transformation. It is inferred that the intense diffusion occurs on this stage. In the crept specimen, $\mathrm{M}_{7} \mathrm{C}_{3}$ remains for longer time than in the tempered specimen (Table 3). This fact is attributed to the creep stress, which leads larger fresh quantities of

Table 2. Identified precipitates of the unstressed specimen.

\begin{tabular}{|c|c|c|c|c|c|}
\hline & & $10 \mathrm{~h}$ & & $100 \mathrm{~h}$ & $1000 \mathrm{~h}$ \\
\hline $550^{\circ} \mathrm{C}$ & $\mathrm{M}_{3} \mathrm{C}$ & $\mathrm{M}_{7} \mathrm{C}_{3} \mathrm{MX}$ & $\mathrm{M}_{7} \mathrm{C}_{3}$ & $\mathrm{M}_{23} \mathrm{C}_{6} \mathrm{MX}$ & $\mathrm{M}_{23} \mathrm{C}_{6} \mathrm{MX}$ \\
\hline $600^{\circ} \mathrm{C}$ & $\mathrm{M}_{7} \mathrm{C}_{3}$ & $\mathrm{M}_{23} \mathrm{C}_{6} \mathrm{MX}$ & $\mathrm{M}_{23} \mathrm{C}_{6}$ & MX & $\mathrm{M}_{23} \mathrm{C}_{6} \mathrm{MX}$ \\
\hline $650^{\circ} \mathrm{C}$ & $\mathrm{M}_{7} \mathrm{C}_{3}$ & $\mathrm{M}_{23} \mathrm{C}_{6} \mathrm{MX}$ & $\mathrm{M}_{23} \mathrm{C}_{6}$ & MX & $\mathrm{M}_{23} \mathrm{C}_{6} \mathrm{MX}$ \\
\hline
\end{tabular}

$\mathrm{M}_{7} \mathrm{C}_{3}$ causing matrix depletion of $\mathrm{Cr}$ and $\mathrm{C}$; this thereby leads the retardation of $\mathrm{M}_{7} \mathrm{C}_{3} \rightarrow \mathrm{M}_{23} \mathrm{C}_{6}$ reaction. $^{19)}$

The precipitation characteristics of $\mathrm{M}_{23} \mathrm{C}_{6}$ are shown in Photo. 2. In the crept specimen, the following orientation relationships between $\mathrm{M}_{23} \mathrm{C}_{6}$ and ferrite matrix have been found.

$$
\begin{aligned}
& \left(\begin{array}{l}
(\overline{\mathrm{l}} 00)_{\mathrm{M}_{23} \mathrm{C}_{6}} / /(100)_{\alpha} \\
{[001]_{\mathrm{M}_{23} \mathrm{C}_{6}} / /[011]_{\alpha}} \\
{[010]_{\mathrm{M}_{23} \mathrm{C}_{6}} / /[0 \overline{1} 1]_{\alpha}}
\end{array}\right)\left(\begin{array}{l}
(1 \overline{1} 1)_{\mathrm{M}_{23} \mathrm{C}_{6}} / /(01 \overline{2})_{\alpha} \\
{[\overline{\mathrm{I}} 01]_{\mathrm{M}_{23} \mathrm{C}_{6}} / /[12 \overline{1}]_{\alpha}} \\
{[\overline{2} \overline{\mathrm{l}} 1]_{\mathrm{M}_{23} \mathrm{C}_{6}} / /[32 \overline{1}]_{\alpha}}
\end{array}\right) \\
& \left(\begin{array}{l}
(011)_{\mathrm{M}_{23} \mathrm{C}_{6}} / /(111)_{\alpha} \\
{[311]_{\mathrm{M}_{23} \mathrm{C}_{6}} / /[\overline{1} 2 \overline{1}]_{\alpha}} \\
{[11 \overline{1}]_{\mathrm{M}_{23} \mathrm{C}_{6}} / /[\overline{\mathrm{l}} 10]_{\alpha}}
\end{array}\right)
\end{aligned}
$$

The first orientation relationship is also found in the tempered specimen. The results of some works ${ }^{14,20)}$ about the orientation relationship between $\mathrm{M}_{23} \mathrm{C}_{6}$ and ferrite matrix are different from the present one. This fact implies that crystal structure of $\mathrm{M}_{23} \mathrm{C}_{6}$ can be changed by additioning of various alloying elements. The crystal structure of $\mathrm{M}_{23} \mathrm{C}_{6}$ type carbides was shown to be a complex face centered cubic type. ${ }^{21)}$ It is considered that this type has little coherency with

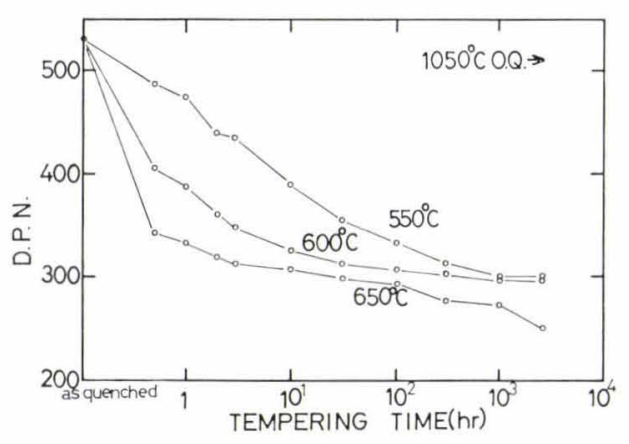

Fig. 7. Tempering characteristics.

Table 3. Precipitation characteristics.

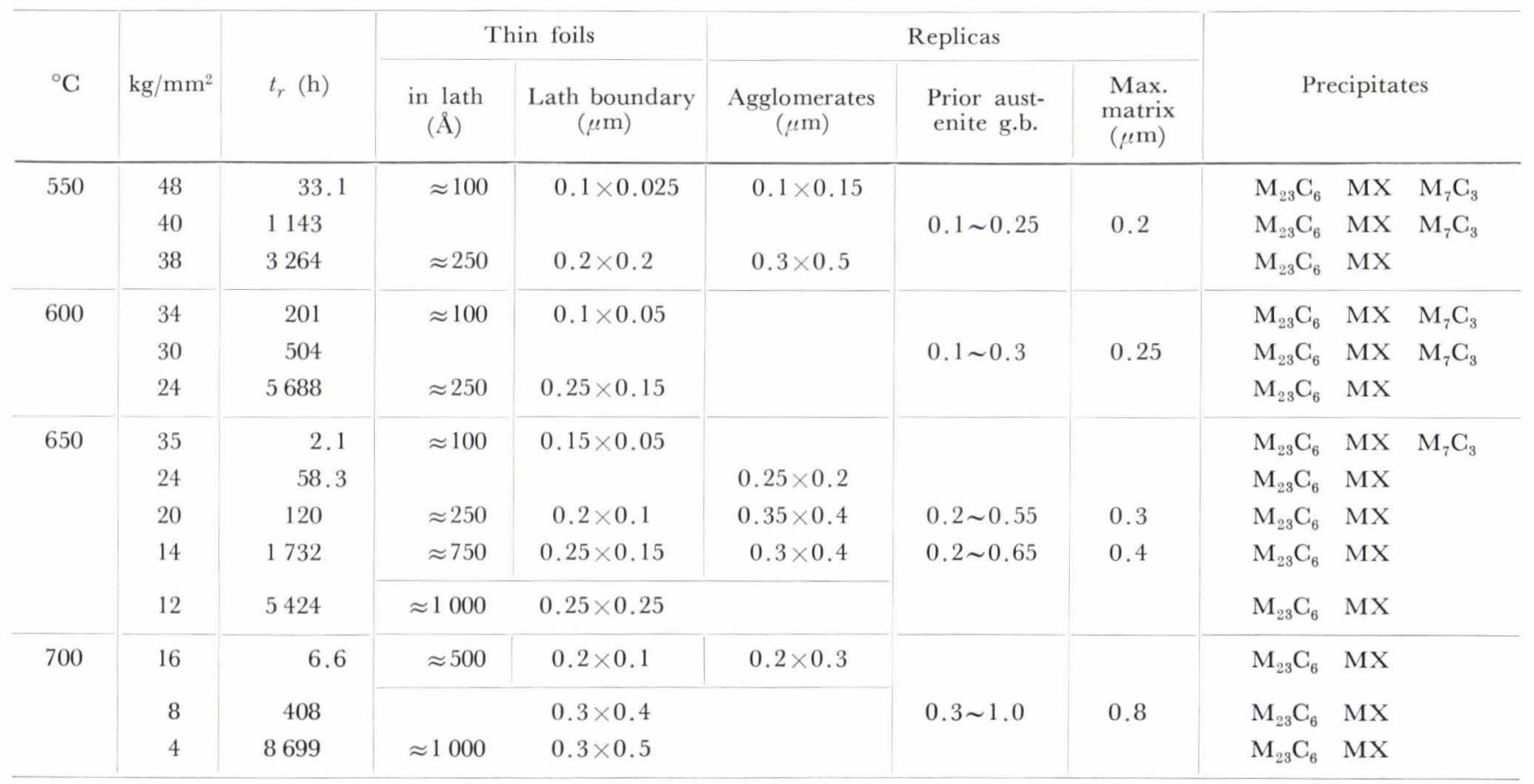




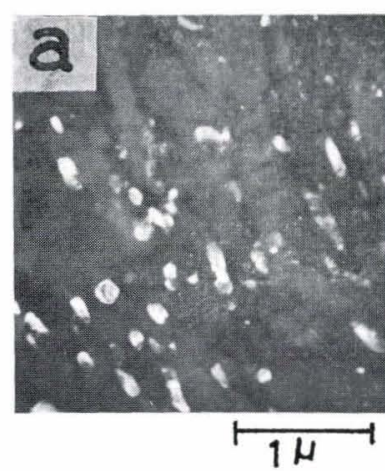

(a) Dark field image

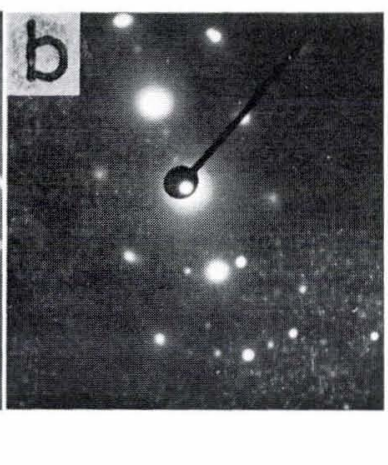

(b) Electron diffraction pattern

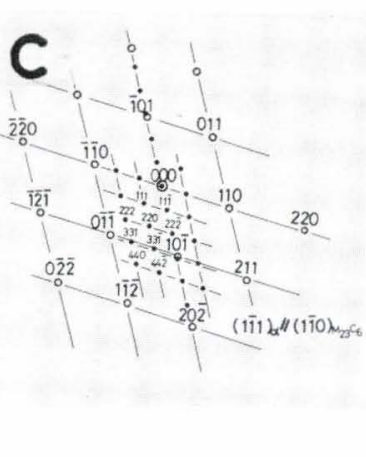

(c) Key diagram

Photo. 2. Transmission electron micrographs showing the precipitation of $\mathrm{M}_{23} \mathrm{C}_{6}$.

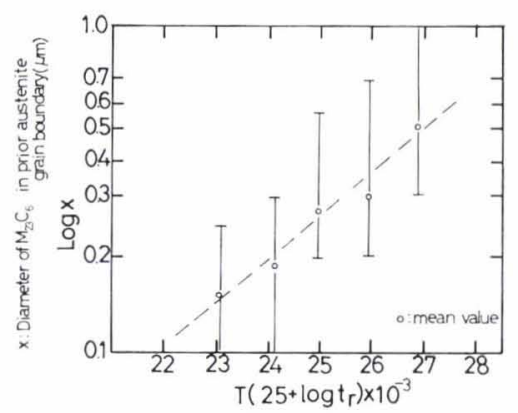

Fig. 8. Diameter change of $\mathrm{M}_{23} \mathrm{C}_{6}$ in prior austenite grain boundary.

the ferrite atom and exhibits various crystal orientation, especially in the stressed condition.

In the $150 \mathrm{kV}$ electron microscope, it was impossible to identify very fine precipitates $(100 \approx 200 \AA)$ within the martensite lath which attribute to high creep resistance by the inhibition effects of dislocation movements. However, fine precipitates $(\approx 300 \AA)$ paired with $\mathrm{M}_{23} \mathrm{C}_{6}$ and fine spherical precipitates remained in the subgrain in long term tested specimen was identified as the cubic type of $(\mathrm{V}, \mathrm{Nb}) \mathrm{C}$ by selected-area electron diffraction. The diameter change of $\mathrm{M}_{23} \mathrm{C}_{6}$ in prior austenite grain boundary as a function of the Larson-Miller parameter are shown in Fig. 8. Between Larson-Miller parameter and diameter change of $\mathrm{M}_{23} \mathrm{C}_{6}$, an approximate linear relationship was observed.

\section{Microstructure}

\section{Microstructure of the Crept Specimen at $550^{\circ} \mathrm{C}$}

High creep resistance of this steel at $550^{\circ} \mathrm{C}$ is attributed to the dislocation pinning effect of very fine precipitates within the lath (Photo. 3 (a)); these precipitates give high internal friction and high coherent strains with the ferrite matrix. Electron micrograph of a crept specimen at $40 \mathrm{~kg} / \mathrm{mm}^{2}\left(t_{r}\right.$ : rupture time $=$ $1143 \mathrm{~h}$ ) shows (Photo. 3 (b)) clearly a lath martensite structure with high dislocation density. $\mathrm{M}_{23} \mathrm{C}_{6}$ at the lath boundary is about $0.15 \times 0.05 \mu \mathrm{m}$ in size and the very fine precipitate within the lath is about $200 \AA$ in size. A diffused dislocation cell has formed within some laths. Electron micrograph (Photo. 3 (c)) at $38 \mathrm{~kg} / \mathrm{mm}^{2}\left(t_{r}=3264 \mathrm{~h}\right)$ shows a dislocationprecipitates tangled structure within the lath, where- as more polygonized region was observed compared with electron micrograph at $40 \mathrm{~kg} / \mathrm{mm}^{2}$. In the electron micrograph (Photo. $3(\mathrm{~d}))$ at $34 \mathrm{~kg} / \mathrm{mm}^{2}\left(t_{r}=\right.$ $8976 \mathrm{~h}$ ), two-stepped tempering, preferential coagulation of $\mathrm{M}_{23} \mathrm{C}_{6}$ at some lath boundaries and fractured lath boundaries caused by the lath boundary sliding was observed. Up to $9000 \mathrm{~h}$ of the ruptured time, however, the precipitation of very fine precipitates within the lath is continuing and subgrain formation with polygonization is not yet prevailing.

\section{Microstructure of the Crept Specimen at $600^{\circ} \mathrm{C}$}

Microstructural change of the crept specimen at $600^{\circ} \mathrm{C}$ takes place in the same way as that at $550^{\circ} \mathrm{C}$. It is clearly seen that dislocation cells form within the martensite lath in the electron micrograph (Photo. 3 (e)) at $30 \mathrm{~kg} / \mathrm{mm}^{2} \quad\left(t_{r}=504 \mathrm{~h}\right)$. Electron micrograph (Photo. 3 (f)) at $24 \mathrm{~kg} / \mathrm{mm}^{2}\left(t_{r}=5688 \mathrm{~h}\right.$ ) shows the early stage of subgrain formation in some polygonized regions, but the morphology of the lath is not yet changed. The morphology of $\mathrm{M}_{23} \mathrm{C}_{6}$, which is the main carbide of this steel, changes as follows; needle type $(0.1 \times 0.025 \mu \mathrm{m}) \rightarrow$ planer type $(0.2 \times$ $0.05 \mu \mathrm{m}) \rightarrow$ spindle type $(0.2 \times 0.1 \mu \mathrm{m}) \rightarrow$ spherical type $(0.2 \times 0.2 \mu \mathrm{m}) \rightarrow$ granular type $0.3 \times 0.2 \mu \mathrm{m})$.

\section{Microstructure of the Crept Specimen at $650^{\circ} \mathrm{C}$}

At $650^{\circ} \mathrm{C}$, almost all the stages of the creep recovery process were observed; cell formation within the lath $\rightarrow$ subgrain formation with polygonization $\rightarrow$ sub-boundary migration with the coalescence of $\mathrm{M}_{23} \mathrm{C}_{6}$ at the lath boundary $\rightarrow$ subgrain coalescence. Electron micrograph (Photo. 4 (a)) at $35 \mathrm{~kg} / \mathrm{mm}^{2}$ $\left(t_{r}=2.1 \mathrm{~h}\right)$ shows a dislocation-precipitates tangled structure similar to the microstructure at $550^{\circ} \mathrm{C}$. In the electron micrographs (Photos. 4 (b) and (c)) at $24 \mathrm{~kg} / \mathrm{mm}^{2}\left(t_{r}=58.3 \mathrm{~h}\right)$ and $20 \mathrm{~kg} / \mathrm{mm}^{2} \quad\left(t_{r}=120 \mathrm{~h}\right)$, the spherical type of $\mathrm{M}_{23} \mathrm{C}_{6}$ at the lath boundary and the spindle or spherical type of $\mathrm{M}_{23} \mathrm{C}_{6}$ slightly spaced from the lath boundary is observed. The orientation of $\mathrm{M}_{23} \mathrm{C}_{6}$ slightly spaced from the lath boundary is the same as that of the lath boundary $\mathrm{M}_{23} \mathrm{C}_{6}$. This precipitation characteristic was considered as a result of the lath boundary migration which can easily ocurr in creep condition. In general, small misorientation (about $1^{\circ}$ ) between martensite laths leads the lath boundary migration easily. Electron micrographs (Photos. 4 (d) and (e)) at $16 \mathrm{~kg} / \mathrm{mm}^{2} \quad\left(t_{r}=582 \mathrm{~h}\right.$ ) show that the subgrain formation has started in some 

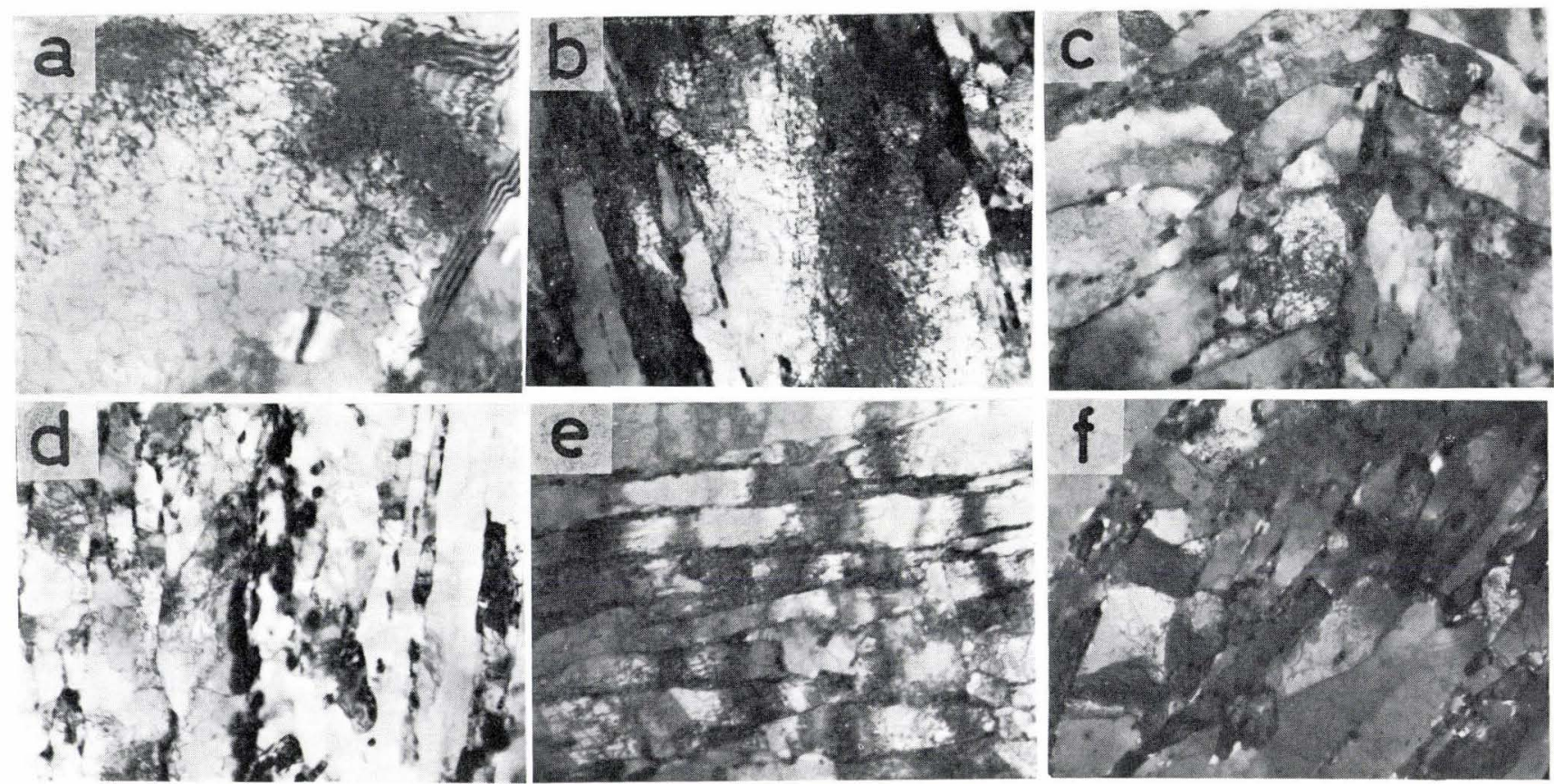

\section{a}
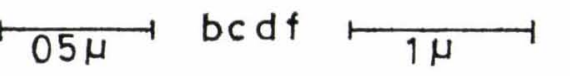

e

$550^{\circ} \mathrm{C}$; (a) $33.1 \mathrm{~h}-48 \mathrm{~kg} / \mathrm{mm}^{2}$, (b) $1143 \mathrm{~h}-40 \mathrm{~kg} / \mathrm{mm}^{2}$, (c) $3264 \mathrm{~h}-38 \mathrm{~kg} / \mathrm{mm}^{2}$, (d) $8976 \mathrm{~h}-34 \mathrm{~kg} / \mathrm{mm}^{2}$ $600^{\circ} \mathrm{C}$; (e) $504 \mathrm{~h}-30 \mathrm{~kg} / \mathrm{mm}^{2}$, (f) $5688 \mathrm{~h}-24 \mathrm{~kg} / \mathrm{mm}^{2}$

Photo. 3. Transmission electron micrographs.

polygonized regions. From this point, martensite lath boundaries start to be curved with the coarsening of $\mathrm{M}_{23} \mathrm{C}_{6}$ and sometimes to be fractured by the lath boundary sliding which is accelerated by the creep stress. Further, the diffused dislocation cell changes to the sharped one. Electron micrographs (Photos. 4 (f) and (g)) at $14 \mathrm{~kg} / \mathrm{mm}^{2}\left(t_{r}=1732 \mathrm{~h}\right.$ ) show the sub-boundary migration and subgrain growth. Occasionally carbides inhibits the subboundary migration as well as pins the dislocation. Comparing the electron micrographs at $14 \mathrm{~kg} / \mathrm{mm}^{2}$ with those at $16 \mathrm{~kg} / \mathrm{mm}^{2}$, the mean diameter of subgrain increases by a factor of $\sim 20$ and dislocation density decreases considerably. Electron micrograph (Photo. $4(\mathrm{~h}))$ at $12 \mathrm{~kg} / \mathrm{mm}^{2} \quad\left(t_{r}=5424 \mathrm{~h}\right.$ ) shows a recrystallized substructure which has large equiaxed subgrains and agglomerated $\mathrm{M}_{23} \mathrm{C}_{6}$ precipitates at high angle grain boundaries; the precipitates have no more effect on the dislocation movements.

\section{Microstructure of the Crept Specimen at $700^{\circ} \mathrm{C}$}

At $700^{\circ} \mathrm{C}$, the creep recovery proceeds rapidly and the recrystallized substructure is observed in the short term test specimen. Electron micrographs (Photos. 5 (a) and (b)) at $8 \mathrm{~kg} / \mathrm{mm}^{2}\left(t_{r}=408 \mathrm{~h}\right.$ ) show that the sub-boundary migration and subgrain growth are occurring. Two different regions were sometimes observed in the same thin foils. One shows a high dislocation density with fine precipitated in the subgrain, whereas the other shows a low dislocation density with the preferentially coarsened $\mathrm{M}_{23} \mathrm{C}_{6}$ at the subgrain boundary and the remained MX phase in the subgrain. This fact was interpreted as that the softening rate of the surface region differs from that of the core region. Electron micrograph (Photo. 5 (c)) at $4 \mathrm{~kg} / \mathrm{mm}^{2}\left(t_{r}=8699 \mathrm{~h}\right)$ shows a heavily recrystallized substructure. The mean diameter of the subgrain is increased by a factor of $\sim 10$ compared with that of the subgrain at $8 \mathrm{~kg} / \mathrm{mm}^{2}$.

\section{Summary of the Microstructral Change}

The microstructure and dislocation density change as a function of the Larson-Miller parameter are shown in Figs. 9 and 10 . The observed microstructual change of crept specimens can be divided into four stages when it is expressed as a function of the Larson-Miller parameter. Figure 9 (a) shows the early stage $(\mathrm{L} . \mathrm{M} \approx 21.5)$ of the creep recovery. The very fine precipitates $(100 \sim 250 \AA)$ within the martensite lath contributes to the high creep resistance by the pinning action of dislocation movements. The morphology of the lath boundary is the straight type and the width of the lath is small. At the second stage $(\mathrm{L} . \mathrm{M} \approx 23.5)$ of the recovery process, fine precipitates within the lath start coarsening by Ostwald-ripening and the diffused dislocation cell has formed within the lath. In this steel, the fine precipitates within the lath grew according to a $t^{n}$ laws, with $n \approx \frac{1}{4} \sim \frac{1}{5}$ at $550^{\circ}$ to $600^{\circ} \mathrm{C}$ and $n \approx \frac{1}{3}$ at $650^{\circ} \mathrm{C}$ in the creep condition. From this stage, the dislocation density within the lath starts to decrease (Fig. 10), but in this steel which contains optimum amounts of secondary hardening elements Mo, $\mathrm{V}$ and $\mathrm{Nb}$, which have high activation energies for diffusion, the thermal activation of the annihilation of dislocations is much retarded. The activation energy for the minimum creep rate was found to be $95 \sim 100$ 

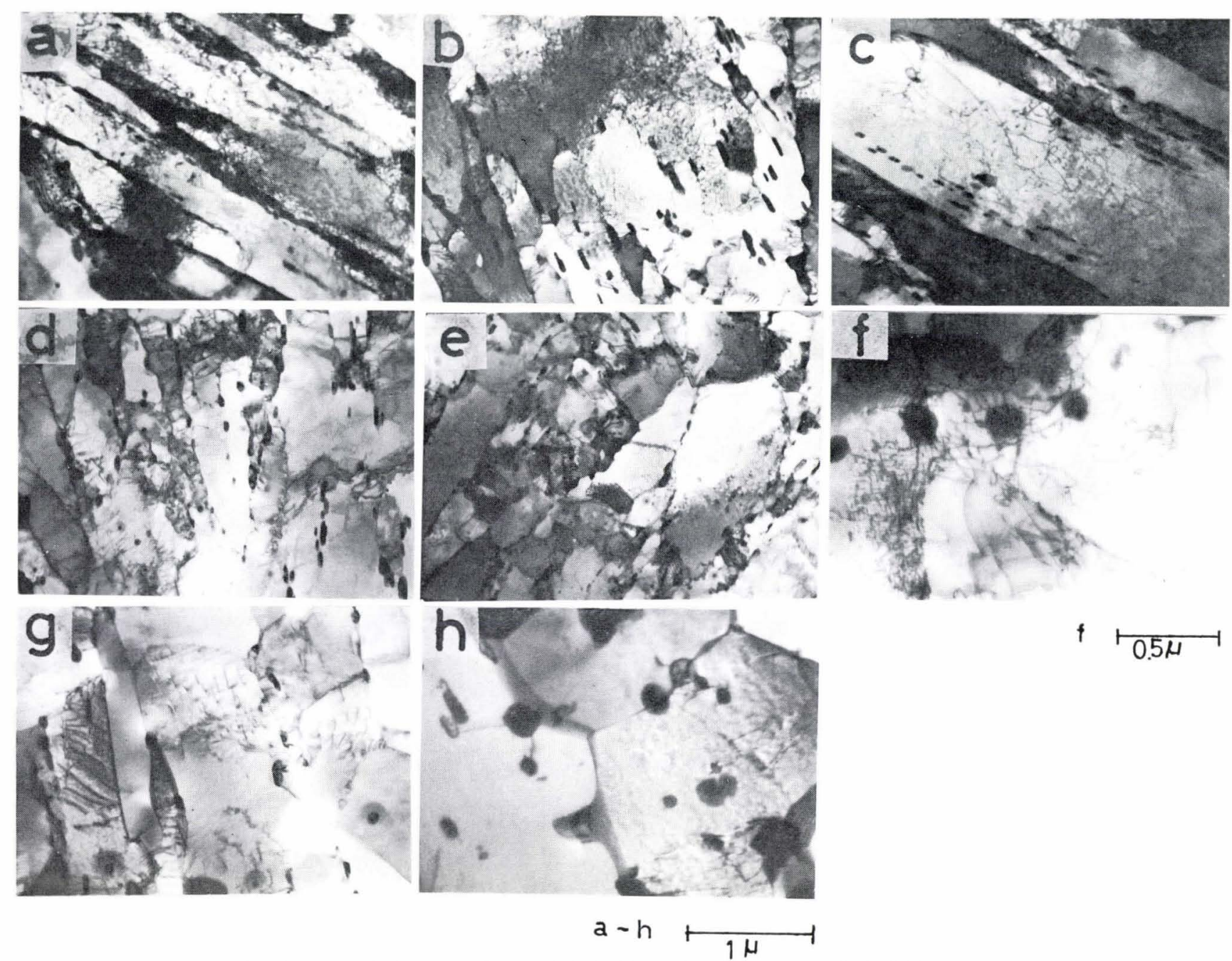
$650^{\circ} \mathrm{C}$; (a) $2.1 \mathrm{~h}-35 \mathrm{~kg} / \mathrm{mm}^{2}$
(d) $582 \mathrm{~h}-16 \mathrm{~kg} / \mathrm{mm}^{2}$
(b) $58.3 \mathrm{~h}-24 \mathrm{~kg} / \mathrm{mm}^{2}$
(c) $120 \mathrm{~h}-20 \mathrm{~kg} / \mathrm{mm}^{2}$
(g) $1732 \mathrm{~h}-14 \mathrm{~kg} / \mathrm{mm}^{2}$
(e) $582 \mathrm{~h}-16 \mathrm{~kg} / \mathrm{mm}^{2}$
(f) $1732 \mathrm{~h}-14 \mathrm{~kg} / \mathrm{mm}^{2}$
(h) $5424 \mathrm{~h}-12 \mathrm{~kg} / \mathrm{mm}^{2}$

Photo. 4. Transmission electron micrographs.
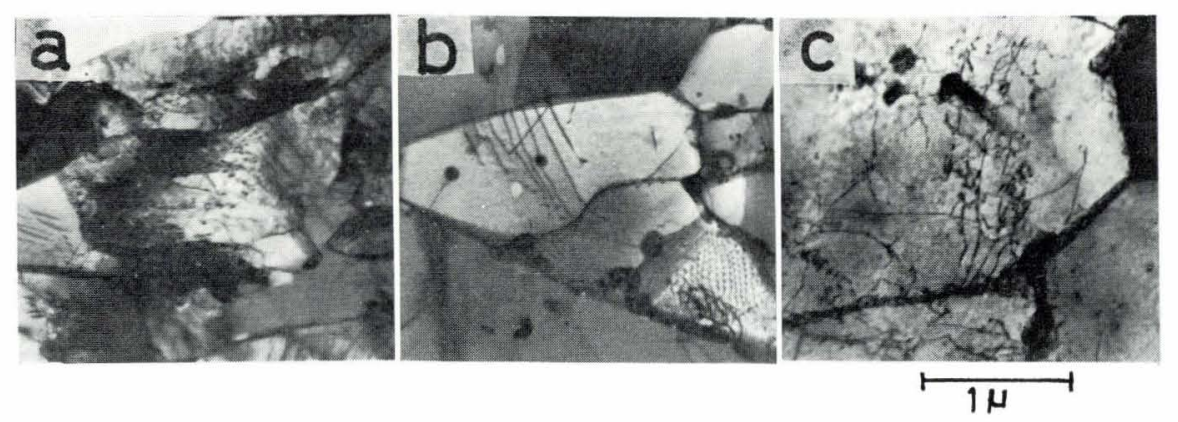

$700^{\circ} \mathrm{C}$; (a), (b) $408 \mathrm{~h}-8 \mathrm{~kg} / \mathrm{mm}^{2}$, (c) $8699 \mathrm{~h}-4 \mathrm{~kg} / \mathrm{mm}^{2}$

Photo. 5. Transmission electron micrographs.

$\mathrm{kcal} /$ mole for this $12 \mathrm{Cr}-\mathrm{Mo}-\mathrm{V}-\mathrm{Nb}$ steel. At the third stage $(\mathrm{L} . \mathrm{M} \approx 25.0)$, martensite lath boundaries start to change the morphology from the straight type to the curved type as coarsening of $\mathrm{M}_{23} \mathrm{C}_{6}$ at the lath boundary, and the dislocation-precipitates tangled structure changes to a sharp cell substructure. At this stage, the subgrain formation starts in some polygonized regions where the rearrangements of dislocations have increased by the agglomerating and dissolution of the fine precipitates. As recovery proceeds, the sub-boundary is occasionally unpinned by the precipitates and starts to migrate. The subboundary migration is accelerated by the creep stress in the same way as the lath boundary sliding is done. As the unpinned sub-boundary increases, the coalescence of the subgrain (i.e., recrystallization) increases. At the fourth stage ( $\mathrm{L} . \mathrm{M} \approx 26.5)$, a heavily recovered structure is observed, which has a large 
spheroidal $\mathrm{M}_{23} \mathrm{C}_{6}$ at the subgrain boundary and $\mathrm{MX}$ in the subgrain which have no more effect on the creep resistance.

\section{The Effect of Creep Stress}

In order to investigate the effect of creep stress on the microstructure and hardness, the specimen air cooled from $1050^{\circ} \mathrm{C}$ was creep tested by the multispecimen machine, which heats homogeneously both the gauge length and head region of the specimen. The results of hardness measurements are shown in Fig. 11. The Vickers hardness difference observed between the gauge length and head region is about 20 at $550^{\circ} \mathrm{C}$, about 40 at $600^{\circ} \mathrm{C}$ and about 50 at $650^{\circ} \mathrm{C}$. This result indicates that the recovery is accelerated by creep stress, which gives high driving force for the creep recovery.

Electron micrographs (Photo. (6)) of the specimen tested at $650^{\circ} \mathrm{C}$ and $12 \mathrm{~kg} / \mathrm{mm}^{2}\left(t_{r}=2234 \mathrm{~h}\right)$ shows the carbide distribution of the gauge length and head region. The carbide distribution of the head region corresponds to the lath martensite structure and that

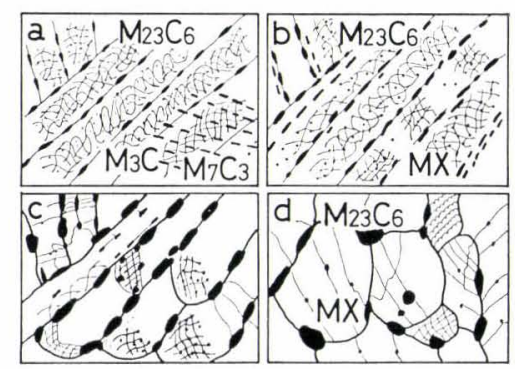

Fig. 9. The model of the creep recovery mechanism for the 12- $\mathrm{Cr}-\mathrm{Mo}-\mathrm{V}-\mathrm{Nb}$ steel.

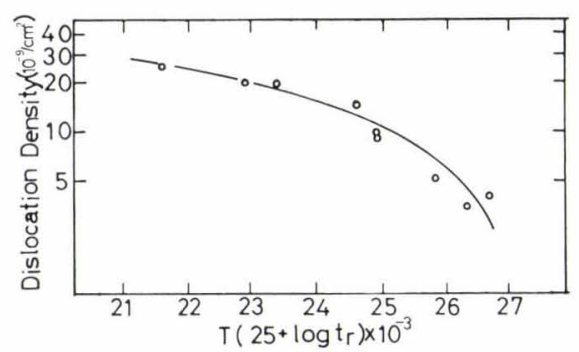

Fig. 10. Dislocation density change as a function of the Larson-Miller parameter. of the gauge length region is correspond to the subgrain growth stage. Microstructures of the crept specimens reveal more clear grain boundaries and larger $\mathrm{M}_{23} \mathrm{C}_{6}$, which is preferentially agglomerated at grain boundary, compared with that of the unstressed specimens. This implies that grain boundary is sinks of dislocations induced by the creep stress, and that pipe diffusion of alloying elements is accelerated on the stage of these dislocation movements.

\section{The Effect of Cooling Rate and Si Decrease}

It was expected that decreasing silicon contents leads a low creep rupture strength by decreasing the lattice parameter of the ferrite matrix. However, the actual difference between the lattice parameters of the $0.5 \% \mathrm{Si}$ and the $0.02 \% \mathrm{Si}-12 \mathrm{Cr}$ steel was measured to be about $5 \times 10^{-4} \AA$. It is very difficult to estimate the effect of this difference on the creep rupture strength, but the high rupture strength of this steel implies that this difference would give little effect on the creep rupture strength compared with that of other alloying elements.

Comparison of creep rupture strength of the oilquenched and the air-cooled steels show that the former has higher creep rupture strengths than the latter; $1000 \mathrm{~h}$ creep rupture strength of oil-quenched steel is higher about $0.5 \sim 1.5 \mathrm{~kg} / \mathrm{mm}^{2}$ than that of the air cooled steel. The oil quenched steel has a martensite-bainite duplex substructure in quenched condition, whereas the air cooled steel has large quantites of bainite whose cementite distribution is similar to that of the low bainite. This indicates that the substructure is changeable according to the cooling rate

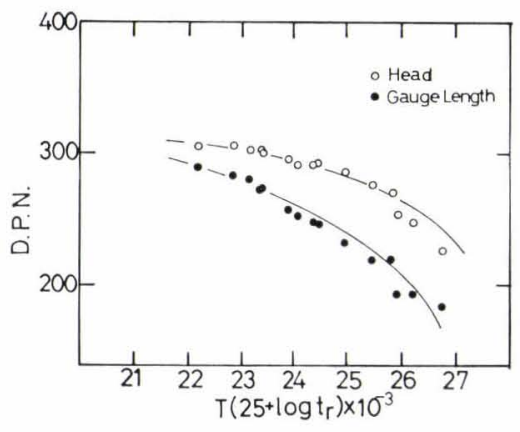

Fig. 11. Effect of creep stress on hardness.

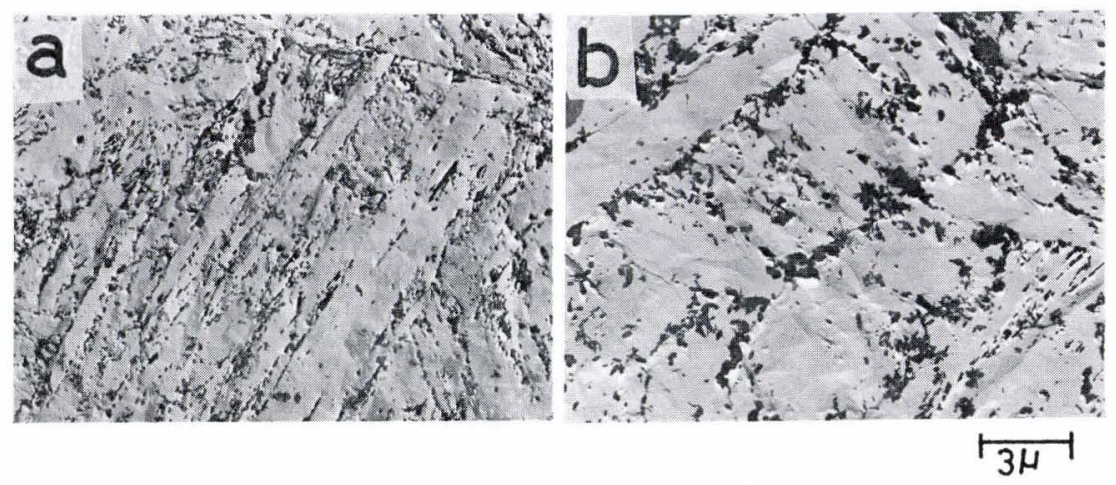

(a) Head region

(b) Gauge Length region

Photo. 6. Transmission electron micrographs showing influence of creep stress (by carbon extraction replicas). $1050^{\circ} \mathrm{C}$ air-cooled, $650^{\circ} \mathrm{C} ; 2234 \mathrm{~h}-12 \mathrm{~kg} / \mathrm{mm}^{2}$. 
from martensite to bainite. In the point of the creep strength, martensite structure is beneficial and oil quenching is necessary.

\section{Conclusions}

The creep rupture strength and microstructure of a low $\mathrm{Si}-12 \mathrm{Cr}-\mathrm{Mo}-\mathrm{V}-\mathrm{Nb}$ steel have been investigated. The results obtained are as follows.

(1) Low $\mathrm{Si}-12 \mathrm{Cr}-\mathrm{Mo}-\mathrm{V}-\mathrm{Nb}$ steel exhibits a superior creep rupture strength 1.4 times that of the conventional super $12 \mathrm{Cr}$ rotor steels. The effect of silicon decrease from $0.5 \%$ to $0.02 \%$ on the creep rupture strength is small. It is considered that this superior creep rupture strength is caused by the optimum additioning of $\mathrm{Mo}, \mathrm{V}$ and $\mathrm{Nb}$, which give rise to high secondary hardening.

(2) According to the transmission electron microscope examination of the crept specimens, the model of the creep recovery mechanism for the $12 \mathrm{Cr}-\mathrm{Mo}-$ $\mathrm{V}-\mathrm{Nb}$ steel is established. Below $600^{\circ} \mathrm{C}$, this steel exhibits high creep resistance which is attributed to the dislocation pinning action of the very fine precipitates within the lath. At $650^{\circ} \mathrm{C}$, a creep recovery process was observed; dislocation cell formation within the lath $\rightarrow$ subgrain formation with polygonization $\rightarrow$ sub-boundary migration with the coalescence of $\mathrm{M}_{23} \mathrm{C}_{6}$ at lath boundary $\rightarrow$ subgrain growth. The structural stability of this steel is remarkable below $600^{\circ} \mathrm{C}$.

(3) Effective austenitizing temperature on the long term creep strength was found to be in the range of $1050^{\circ}$ to $1100^{\circ} \mathrm{C}$. Solution treatment above $1100^{\circ} \mathrm{C}$ is no more effective on the long term creep rupture strength.

(4) Comparison of the creep rupture strengths of the $700^{\circ} \mathrm{C}$ tempered steel and that of the $570^{\circ}+$ $620^{\circ} \mathrm{C}$ tempered one shows that the latter exhibits high creep rupture strength in short test, but a reversed tendency was observed in long term test. The $700^{\circ} \mathrm{C}$ tempered steel, which has a low strength in prior tempered condition but exhibits high creep resistance in long term test, is beneficial.

\section{Acknowledgements}

The authors would like to acknowlege the help of the production of sample of Dr. J. Watanabe, General Manager of Material Reserch Laboratory, The Japan Steel Works Ltd.

\section{REFERENCES}

1) T. Fujita: Report of the 123rd Committee on Heat-Resisting Metals and Alloys, Japan Society for the Promotion of Science, 18 (1977), 3, 335.

2) A. Choudhury, R. Jauch, H. Löwenkamp und F. Tince: Stahl u. Eisen, 97 (1977), 857.

3) K. J. Irvine: Steel for the Power Industry, P. I. Materials in Power Plant, The Chameleon Press Ltd., London, (1975).

4) C. J. Boyle and D. L. Newhouse: Metal Progress, 87 (1965), 61.

5) M. Kawai, K. Kawaguchi, H. Yoshida, E. Kanazawa and S. Mito: Tetsu-to-Hagané, 61 (1975), 229.

6) E. A. Little, D. R. Harries, F. B. Pickering and S. R. Keown: Metal Technology, 4 (1977), 205.

7) K. J. Irvine, D. J. Crowe and F. B. Pickering: JISI, 195 (1960), 386.

8) K. Suzuki, K. Taniguchi and J. Watanabe: The 6th International Vacuum Metallurgy Conference on Special Melting and Metallurgical Coatings, San Diego, California, April, (1979).

9) T. Fujita, T. Sato and N. Takahashi: Trans. ISIJ, 18 (1978), 115.

10) T. Fujita and N. Takahashi: Trans. ISIJ, 18 (1978), 269

11) T. Fujita and N. Takahashi: Trans. ISIJ, 18 (1978), 702.

12) J. Koutsky: JISI, 205 (1967) 763.

13) M. C. Murphy and G. D. Branch: JISI, 206 (1968), 266.

14) A. Hede and B. Aronsson: JISI 206 (1968), 1263.

15) R. K. Ham; Phil. Mag., 6 (1961), 1183.

16) J. Z. Briggs and T. D. Parker: The Super $12 \mathrm{Cr}$ Steels, Climax Molybdenum Co., (1965).

17) T. Fujita: Doctoral Thesis, The University of Tokyo, (1960).

18) M. Tanino: J. Japan Inst. Metals., 6 (1967), 23.

19) V. P. Gupta and P. R. Dhar: JISI, 198 (1963), 213.

20) K. Matsumoto, S. Takeda and Y. Imai: J. Japan Inst. Metals, 33 (1969), 1024.

21) M. Kikuchi, S. Nagakura and S. Oketani: Tetsu-to-Hagané, 57 (1971), 1009. 